\section{The need to change attractors}

\author{
Viele empirische Untersuchungen des Energie- und Maferialverbrauchs zeigen, \\ daß zeitweise durchaus Dematerialisierungsprozesse beobachtbar waren. \\ Allerdings isł die vielfach geäußerte Schlußfolgerung, daß mił steigendem \\ Einkommen eine zunehmende Entkopplung von Wirtschaftswachstum und \\ Ressourcenverbrauch zu erwarten ist, mit Skepsis zu betrachten. Eine ge- \\ navere Analyse zeigt, daß Dematerialisierung und damit Öko-Effizienz auf \\ makroökonomischer Ebene eher ein temporäres Phänomen ist. Sie ist an \\ spezifische institutionelle und technologische Rahmenbedingungen gebunden. \\ Vielfach folgt darauf im Sinn einer N-Kurve ein Wiederanstieg des Material- \\ verbrauchs. Dies kann im Rahmen der evolutorischen Ökonomik über \\ punktuelle Gleichgewichte (Attraktoren) auch plausibel erklärt werden.
}

$\mathrm{C}$ Von Sander de Bruyn onsumption of materials and energy is an important interface between the economy and the environment. Dematerialisation is the term that describes the development where material use per unit of income (or a certain service or product) declines. Dematerialisation is important for sustainable development because (i) it relieves the scarcity constraints to economic development and therefore assures that exhaustion of natural resources can be postponed or prevented, and (ii) it causes pollution to decrease as every resource input sooner or later turns up as emission or waste due to the laws of thermodynamics.

Historical investigations show that dematerialisation indeed has taken place over time. It has been suggested that in the process of on-going economic growth the economy would delink itself from its resource base such that rising incomes can be associated with declining levels of resource inputs and associated pollution (1). Several studies report a large potential for dematerialisation, such that materials and energy intensities in developed economies could be reduced by a factor 4 (2). The question is, however, whether previously reported developments of dematerialisation can be easily extrapolated into the future.

Until the late 1960 s, the consumption of materials, energy and natural resources was believed to grow at the rate of economic growth. This gave rise to growing concerns about the earths' natural resource availability, which was most firmly put forward by the Club of Rome's ,Limits to Growth" (3). The 'limits to growth' have not only been disputed from economic theory. Empirical work has found increasing evidence of a 'slackening' of world material demand since the 1970s. Explanations for the slackening of world materials demand were first put forward by Malenbaum in a theoretical sketch which has later become known as the 'intensity of use hypothesis' (4). According to him income is the explanatory factor in materials consumption. Developing countries with an economic structure relying on subsistence farming typically have a low level of materials and energy consumption. But as industrialisation takes off, countries specialise first on heavy industries to satisfy consumer demand for consumer durables, such as houses, and infrastructure, and therefore materials consumption increases at a faster rate than income. The subsequent induced shift towards service sectors will result in an associated decli- ne in the demand of materials. Hence $\mathrm{Ma}$ lenbaum depicts the relationship between materials demand and income as an inverted-Ushaped curve, today often known as environmental Kuznets curve. Technological change has the effect of shifting the relationship between materials demand and income downwards (see figure 1).

\section{- Continuing dematerialisation?}

The 'intensity of use' hypothesis has been proved in a number of case-studies for specific materials and energy (5). But Labys and Wadell have suggested that a dematerialisation conclusion can be misleading. The demand for materials typically follows a Schumpeterian life-cycle from introduction, via growth and maturity, to saturation and decline. Because the collection of statistics for the consumption of new materials lags behind the introduction and growth-stages, studies using statistical data often observe the saturation and decline stage of materials demand which may not reflect overall dematerialisation but rather materials substitution, or 'transmaterialisation' (6). Resource consumption has consequences for the environment by virtue of the mass balance principle. There would be no reason to assume that environmental pressure decreases due to dematerialisation if only the composition of the materials and energy consumed changes but not the absolute level. Moreover, due to transmaterialisation new substances may enter the environment with serious negative impacts.

Therefore, environmental economists have been investigating ways to construct indicators that represent a better overall picture of the pressure materials and energy consumption exerts on the environment. Such indicators may be indica-

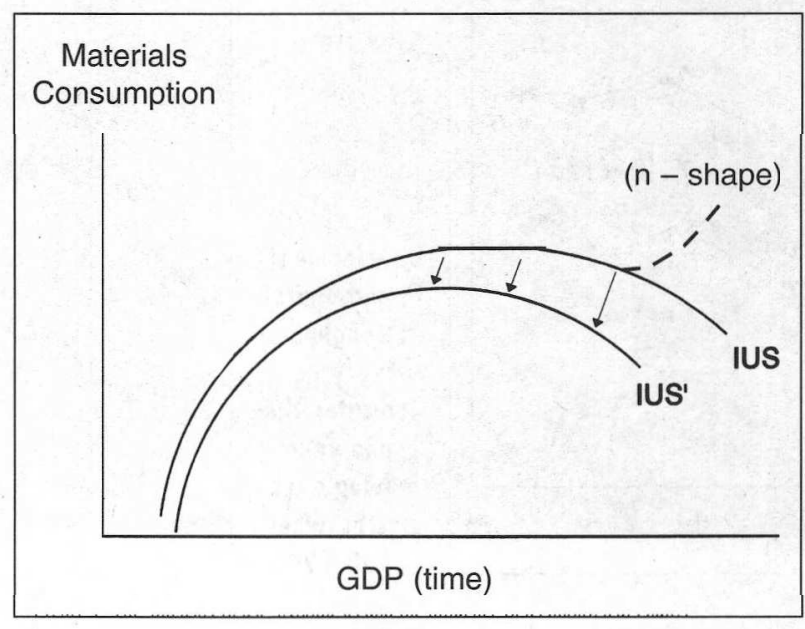

Figure 1: The 'intensity of use' hypothesis and the influence of technological change 
tive of the "throughput" of the economy, defined by Daly as the (entropic) physical flow of matter and energy from nature's sources, through the human economy and back to nature's sinks (7). A crucial issue in the construction of a throughput-indicator is how to add the various types of materials and energy into a single and uniform indicator. Several methods have been proposed, all of which may be critical to the results of empirical applications. Only few empirical studies have formulated and analyzed total throughput using aggregated indicators over time. While e.g. Ayres, based on mass data for the U.S. negates the possibility that dematerialisation is a persistent phenomenon and thereby rejects the dematerialisation hypothesis, this is in contrast to the conclusions of a study by Jänicke et al. (8). They define throughput as the equally weighted level of energy consumption, steel consumption, cement production and weight of freight transport on rail and road (as a general measure of the volume aspect of an economy). The results of their analysis showed that throughput has risen in less developed economies and declined in developed economies in 1985 compared to 1970 , similarly to the intensity of use hypothesis. In subsequent work, Jänicke et al. have re-examined their previous results by enlarging the number of substances and time-frames, and concluded that dematerialisation does not hold for a number of important substances (9). Also the re-examination of the specific results of the first Jänicke study by De Bruyn and Opschoor in an extended time-horizon and with some minor improvements in the indicator calculation suggests that since 1985 there has been an upswing in the levels of throughput for some developed economies.
Aggregated throughput rose again at a rate nearby the rate of economic growth (10). They hence conclude that the actual pattern of throughput over time may be more adequately described as $\mathrm{N}$-shaped, similar to the inverted-U shaped curve but with a subsequent phase of 'rematerialisation' that may continue until new technological breakthroughs would enable another delinking phase (see figure 1).

\section{An evolutionary perspective}

How can this $\mathrm{N}$-shaped pattern of resource use over time be explained? Both technological and structural changes, as leading explanations, have not been confirmed convincing in empirical work. The lack of insight in the driving forces for the relationship between the consumption of materials/energy and income makes it hard to forecast future material demand. $L a b$ son and Crompton have remarked that this is due to the fact that shocks to the relationship between materials demand and income tend not to evaporate over time but introduce a permanent drift in the relationship (11). In the absence of a stable relationship between materials demand and income, predictions cannot be made if the nature and origins of the shocks is not understood.

The effect of shocks on an economic system have been debated in the theoretical literature of evolutionary economics. Two different approaches have been put forward. The first approach originates from an adapted version of the neoclassical model in which technological change depends on investments in 'human capital' that results in innovations and technological change. The corresponding marginal and gradual changes in resource use due to technologi- cal changes are then largely similar to those debated in modern neoclassical economic theories. This approach seems to be able to explain the inverted-u curve in which structural and technological changes gradually lower intensities of use over time in developed economies. However, the N-shaped curve is not satisfactorily explained under this approach.

The second approach suggests that the process of technological change does not follow a smooth process along a path of equilibrium, but is characterized by both disequilibrium and an evolutionary path of learning and selection (12). Innovations over time may typically come in certain clusters as the result of a process of creative destruction, firstly introduced by Schumpeter. Gowdy refers to a punctuated equilibrium view of evolution originating from paleontology and applies this to economics (13). Economic systems may be relatively stable and in an equilibrium during a certain period of time which will be followed by a drastic shift in technological paradigms and institutional and organisational structures. The N-shaped curve may evidence the economic counterpart of the theory of punctuated equilibria, with the positive linkage between throughput and income corresponding to the equilibrium phase.

Hence it is interesting to investigate the character of shocks in the developments in resource use. An easy way to present the patterns of resource use over time is to use phase diagrams where a certain variable is plotted against two dimensions: the value in the current year and the value in the previous year. The various values of the variable over time are then interconnected with a line (14). Dematerialisation, explained by gradual changes, would then show up in phase diagram

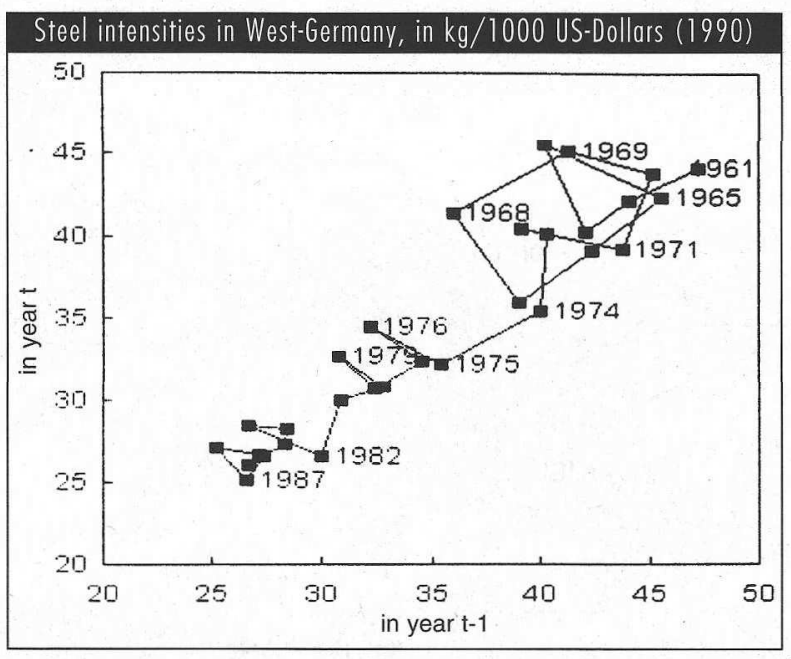

Energy intensities in West-Germany, in toe/1000 US-Dollars (1990)

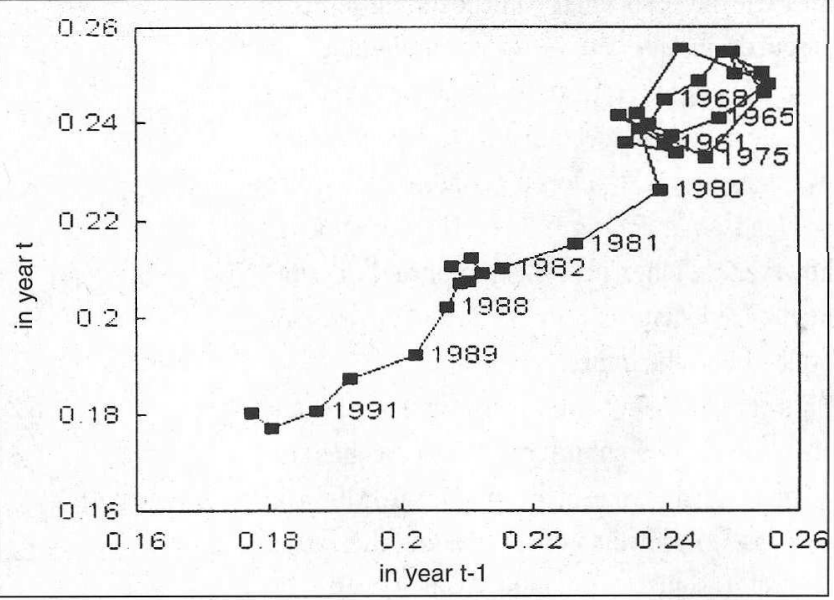

Source: own presentation

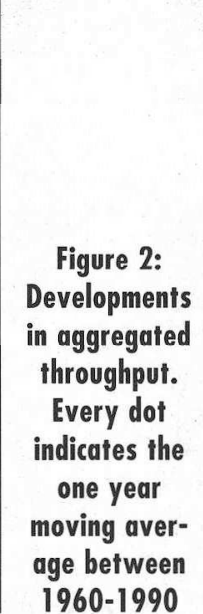

$1960-1990$ 
as a straight negative line, implying lower intensities of use over time. On the other hand, dematerialisation as the result of punctuated equilibria would show various attractor points where the intensity of use remains unchanged for a period of time, followed by drastic shifts in the intensity of use. An application to the development of the consumption of energy and steel per unit of GDP in the Netherlands, United Kingdom, United States and West-Germany for data in the period between 1960-1995 gives clear evidence of attractor points in the data and hence support the punctuated equilibrium theory (15). Figure 2 shows this for West-Germany.

The steel intensities in West-Germany fluctuated around 40kg/ 1000 US\$ from 1960-1973. Afterwards intensities started to fall down until in 1983 a new attractor point had been reached. Also for energy intensities, two attractor points can be found. The first lasted from 1960 to 1979 and the second could be found from 1982-1987. After 1988 energy intensities continued to decline.

Hence the equilibrium state of the economy implies that materials consumption and economic growth are perfectly linked. However, during times of (radical) shifts in technological and institutional paradigms, intensities start to fall rapidly and throughput lowers, at least until the economy stabilizes again around a new attractor point. Then the positive relationship between economic growth and materials consumption is restored and throughput rises again approximately at the same rate as the growth in incomes. The result is a relationship between income and throughput that is N-shaped, similar to the inverted-U shaped curve but with a subsequent stage of rematerialisation. This rematerialisation may continue until a shock, defined above as a change in technological paradigms or institutional structures, will shift the relationship again in the other direction. What the effects will be on longterm total throughput cannot be said beforehand as this depends, amongst others, on the duration

\section{Städtiscbe Nutzung und Verkebr}

ist das Thema des Informationsdienstes Ökologisches Wirtschaften 5-6/99
Wenn Sie potentielle Beiträge haben, wenden Sie sich bitte an die Redaktion.

of the rematerialisation and dematerialisation phases. However, with respect to the examples given above, it can be remarked that the levels of energy and steel consumption in all countries were considerably higher in the 1990 s compared with the early 1960 s. It is therefore likely to suggest that also in the future economic growth will have a bigger influence on material demand than the decreases in the intensity of use.

\section{- Political Implications}

Dematerialisation and rematerialisation may hence be two re-occurring phenomena in the throughput trajectory of developed economies. The environmental implication is that the often promoted argument that economic growth can be beneficial to environmental quality is probably invalid. If the $\mathrm{N}$-shaped figure holds for aggregated material input, a similar development should be traced for aggregated environmentally relevant output (emissions and wastes) by virtue of the mass balance principle. For the policy maker, these results imply that there is few to feel safeguarded that the process of economic growth itself will solve our environmental problems. Instead, institutional and technological breakthroughs may be required to reverse the current trend of rematerialisation into a more environmental benign way. One of these radical changes in the past may have occurred in the years following the first oil crisis when prices of energy and raw materials rose to unprecedented levels and environmental awareness was increasing. These may have triggered governments and business enterprises to reconsider their use of resources and the associated environmental impacts and to start a process of rationalisation, or restructuring. A new stage of eco-restructuring may be required to prevent environmental disturbances to result in irreversible impacts and to shift the positive relationship between income growth and throughput growth (temporarily) in a different direction.

\section{References}

(1) World Bank: Development and the Environment. World Development Report 1992. Oxford University Press, Oxford/New York 1992.

(2) Von Weizsäcker, E.U., A.B. Lovins, L.H. Lovins: Factor Four. Doubling wealth, halving resource use. Earthscan, London 1997.

(3) Meadows, D.: The limits to growth: a report for the Club of Rome's project on the predicament of mankind. Earth Island, London 1972.

(4) Malenbaum, W.: World Demand for Raw Materials in
1985 and 2000. McGrawhill, New York 1978.

(5) E.g. Larson, E.D., M.H. Ross, R.H. Williams: Beyond the Era of Materials. Scientific American, Vol. 254 (1986), p. 34-41;

Herman, R., S.A. Ardekani, J.H. Ausubel: Dematerialization, in: J.H. Ausubel \& H.E. Sladovich (eds): Technology and Environment. National Acadamy Press, Washington, D.C. 1989, p. 50-69.

For a recent study e.g. Nilsson, L.J.: Energy intensity trends in 31 industrial and developing countries 1950-1988. Energy, Vol. 18 (1993), 4, p. 309-322.

(6) Labys, W.C., L.M. Wadell: Commodity lifecycles in US materials demand. Resources Policy, Vol. 15 (1989), p. 238-252.

(7) Daly, H.E.: Steady State Economics. Second Edition with New Essays. Island Press, Washington, DC 1991.

(8) Ayres, R.U.: Industrial Metabolism. In: J.H. Ausubel, H.E. Sladovich (Eds.): Technology and Environment. National Academy Press, Washington, D.C. 1989, p. 23-50;

Jänicke, M., H. Mönch, T. Ranneberg, U.E. Simonis: Economic Structure and Environmental Impacts: East-West Comparisons. The Environmentalist, Vol. 9 (1989), p. 171-182.

(9) Jänicke, M. H. Mönch, M. Binder : Umweltentlastung durch industriellen Strukturwandel? Eine explorative Studie über 32 Industrieländer. Edition Sigma, Berlin 1992. Jänicke, M. et al.: 'Dirty Industries': Patterns of Change in Industrial Countries, Environmental and Resource Economics, Vol. 9 (1997), p. 467-491.

(10) De Bruyn, S.M., J.B. Opschoor: Developments in the throughputincome relationship: theoretical and empirical observations. Ecological Economics, Vol. 20 (1997), p. 255-268. (11) Labson, B.S., P.L. Crompton: Common Trends in Economic Activity and Metals Demand: Cointegration and the Intensity of Use Debate. Journal of Environmental Economics and Management, Vol. 25 (1993), p. 147-161. (12) Dosi, G. L. Orsenigo: Coordination and transformation: an overview of structure, behaviours and change in evolutionary environments. In: Dosi, G., C. Freeman, R. Nelson, G. Silverberg, L. Soete (Eds): Technical change and economic theory, Pinter Publishers Ltd., London 1988.

(13) Gowdy, John M.: Coevolutionary Economics: The Economy, Society and the Environment. Dordrecht: Kluwer Academic Publishers 1994.

(14) For methodological details and an application to employment issues of. Ormerod, P.: The Death of Economics. Faber and Faber, London 1994.

(15) De Bruyn, S.M.. Economic Growth and the Environment: An empirical assessment. Forthcoming at Thesis Publishers, Amsterdam, North-Holland 1999.

\section{Der Autor}

Sander de Bruyn is researcher at the Free University Amsterdam.

Kontakt: Institute of Environmental Studies/Department of Spatial Economics, De Boelelaan 1115,

1081 HV Amsterdam. Tel. 0031-20-4449515,

E-mail: Sander.de.Bruyn@ivm.vu.nl 
(c) 20I0 Authors; licensee IÖW and oekom verlag. This is an article distributed under the terms of the Creative Commons Attribution Non-Commercial No Derivates License (http://creativecommons.org/licenses/by-nc-nd/3.o/), which permits unrestricted use, distribution, and reproduction in any medium, provided the original work is properly cited. 